This item was submitted to Loughborough's Research Repository by the author.

Items in Figshare are protected by copyright, with all rights reserved, unless otherwise indicated.

\title{
Management pathways for the floodplain wetlands of the southern Murray- Darling Basin: Lessons from history
}

PLEASE CITE THE PUBLISHED VERSION

PUBLISHER

Wiley

VERSION

AM (Accepted Manuscript)

\section{PUBLISHER STATEMENT}

This is the peer reviewed version of the following article: GELL, P.A., REID, M.A. and WILBY, R.L., 2019. Management pathways for the floodplain wetlands of the southern Murray-Darling Basin: Lessons from history. River Research and Applications, 35 (8), pp.1291-1301, which has been published in final form at https://doi.org/10.1002/rra.3515. This article may be used for non-commercial purposes in accordance with Wiley Terms and Conditions for Use of Self-Archived Versions.

\section{LICENCE}

CC BY-NC-ND 4.0

\section{REPOSITORY RECORD}

Gell, Peter A., Michael A. Reid, and Robert Wilby. 2019. "Management Pathways for the Floodplain Wetlands of the Southern Murray-darling Basin: Lessons from History". figshare. https://hdl.handle.net/2134/9752936.v1. 

lessons from history

\section{Running head: Management pathways for the Murray Darling Basin}

Peter A. Gell*, School of Health and Life Sciences, Federation University Australia, Ballarat, Vic., AUSTRALIA, p.gell@federation.edu.au

Michael A. Reid, Geography and Planning, University of New England, Armidale, NSW, AUSTRALIA.

Robert L. Wilby, Department of Geography and Environment, Loughborough University, Loughborough, LE11 3TU, UK

\section{Abstract}

The condition of floodplain wetlands of the Murray Darling Basin (MDB) reflects the combined effects of climate variability, river regulation, vegetation clearance and the impacts of human settlement and industry. Today these systems are degraded, in large part due to changes in the hydroecology of waterways arising from water diversion and abstraction to sustain irrigated agriculture. The MDB Plan directs substantial investment towards the restoration of ecosystems largely via the buyback of water allocations, under a cap-and-trade system, for use as environmental flows. This region is projected to receive less winter rainfall and runoff which could exacerbate the impact of water diversions. Long term climate records suggest a higher level of resilience to drying than may be inferred from modern studies. Further, palaeoecological records of change reveal that many wetlands that are perennial today were once naturally seasonal or intermittent, and that much wetland degradation predates regulation and can be attributed to declines in water quality, rather than quantity. A mix of approaches to rehabilitate this long-degraded system, planned and implemented over an extended period, may meet the demands of the Water Act of 2007, but also support the regional economy. An adaptive management approach offers a framework within which to map system vulnerabilities, characterise climate pressures, identify adaptation options, and monitor outcomes, along a pathway to a sustainable future. Early lessons show the extent to which such a deliberative framework can assist water reform under changing socio-economic priorities and external hydroclimatic pressures.

\section{Keywords}

Adaptation pathways, Murray Darling Basin, paleolimnology, wetlands, water resources, climate change 


\section{Introduction}

Among the large rivers of the world, the Murray and Darling represent outliers in being borne in relatively low altitude watersheds ( $\sim 2100 \mathrm{~m}$ and $\sim 1500 \mathrm{~m}$ respectively), yielding relatively small volumes of water and traversing semi-arid to arid landscapes. This is particularly true for the Darling River, which forms the northern half of the Murray-Darling Basin (Figure 1). Despite this, the rivers of the Murray Darling Basin (MDB) provide a vital moisture subsidy to the arid interior of Australia (Morton et al. 1995; Ogden et al. 2007). The ecosystems supported by these rivers provided abundant resources for the first Australians resulting in these riverine landscapes being among the most heavily populated areas on the continent prior to European invasion (Reid et al 2016). To the Europeans, these rivers were avenues for transport of agricultural produce to market in the emerging colonial economy following the gold rush period of the mid-late 1800s. Soon irrigation technologies were implemented to increase food production for the growing population of Australia. Climate variability impacted the reliability of both travel and production and, river regulation, in the form of the construction of many locks and weirs, was the engineering solution to this challenge. The Snowy Mountains Scheme redirected waters inland to generate electricity and supplement the flow of these sluggish rivers to create Australia's agricultural food bowl.

This brief history only sketches the range and intensity of drivers of ecosystem degradation to the river ecosystems of the Murray River. After 60,000 years or more of occupation by the first Australians (Clarkson et al. 2017), their displacement by Europeans in the southeast of the continent coincided with abrupt impacts on the aquatic systems (Dubois et al., 2018). From the 1850s, gold diggings stripped large areas of woodland and actively mobilised soil surfaces leading to the transport of an estimated $\sim 500 \mathrm{M} \mathrm{m}^{3}$ of sediment into MDB streams from Victoria alone (Davies et al., 2018). Land clearance paved the way for widespread sheep grazing that mobilised those soils that had remained intact through the gold years. The absence of wastewater treatment from settlements caused the rivers to become enriched such that they were considered greatly polluted by the late $19^{\text {th }}$ century (Davis et al., 1902). The clearance of recharge zones in the uplands, and the over-application of irrigation waters in the floodplain, filled saline aquifers drawing connate salts to the surface to leak into drainage lines and ultimately into rivers (Macumber, 2001). Then, 
emboldened by a phase of relatively reliable rainfall, water was over-allocated for agricultural consumption from the 1950s (Figure 2) in concert with a great acceleration of water resource development worldwide (MEA, 2005). In-stream disturbance was exacerbated by the proliferation of exotic fish (e.g. carp) from the 1960s. This cocktail of stressors substantially changed the nature of floodplain wetlands. The region is presently experiencing a drying climate with significant droughts and scenarios of diminished winter rainfall owing to shifts in atmospheric circulation (Mills et al., 2013).

Today, the wetland and floodplain ecosystems of the MDB are degraded with only remote sub-catchments in the north identified as being in good condition (Davies et al., 2010). The impact of drought and flow allocation for irrigation focused attention on water volume as the primary means of restoring wetland ecosystems. The 2007 Water Act provided a charter for governments to restore the MDB's ecosystems by prioritising environmental values under the MDB Plan. This sought to recover 2750 Gigalitres per year (GL/yr) through increased water use efficiencies and water buybacks from industry (MDBA, 2013). The allocation of a further $450 \mathrm{GL} / \mathrm{yr}$ is dependent on evidence that no socio-economic hardship will ensue. The combined volume of $3200 \mathrm{GL} / \mathrm{yr}$ would represent the return of one quarter of the mean annual flow, equivalent to $35 \%$ of contemporary water allocations.

The MDB Plan has impacted the economies of many communities in the MDB (RMCG, 2016). In response, regional groups are mounting protests over the impact that reduced allocations are having on production and livelihoods (Jones 2019). The acute nature of this intervention and the level of opposition it has generated prompts a review into the means by which government, with jurisdiction over the MDB, reconciles competing environmental and socio-economic interests. Specifically, insight is needed into how society might best rehabilitate wetland ecosystems while maintaining the socio-economic underpinnings of the communities in the MDB who derive their incomes from irrigation and associated industries.

This paper examines the prospect of applying an adaptive management pathways approach to addressing the impact both of past practices and an expected future drying climate. First it reviews the history of the degradation of the MDB's wetlands to best identify the stressors of ecological state to qualify the degree to which water volume alone is the critical factor for waterway restoration. Second it evaluates climate scenarios to best evaluate the 
magnitude of the challenge ahead in managing both aquatic ecosystems and the socioeconomic systems under increasing water stress. It then evaluates socio-economic approaches underpinning the present management regime and compares them with an approach that plans decision points in the future to tailor adaptation to scenarios while levelling the costs across multiple generations.

\section{Evidence for degradation over the long term}

While monitoring of the condition the MDB commenced relatively recently (1990s), the wetlands themselves, when permanently inundated, have recorded their condition by way of often continuous sediment sequences. Over 60 such sediment records have been recovered and many have revealed substantial changes over time, particularly since the European arrival (Gell \& Reid, 2014; 2016). The pre-European condition of wetlands is evident from a subset of 10-15 permanent wetlands with long sediment sequences (Gell, 2019 , in press). These sites reveal baseline sedimentation rates of $0.1-1 \mathrm{~mm} / \mathrm{a}$. Preserved diatom remains generally suggest sustained rich, aquatic macrophyte communities under clear water conditions providing complex habitats for fauna (Davidson et al. 2013; Reid et al 2007). Most wetlands were also fresh, yet some lakes in the lower MDB were saline in the past (Gell et al., 2005).

The upper sediments of these records, and those from wetlands with shorter sequences, chart human impacts from early in the phase of European settlement. Increased sediment accumulation rates attest to pulses of sediment from unknown sources, but most likely that released from mining centres and through catchment erosion, much through bank collapse or gullying higher in the catchment. This sediment is implicated in the loss of submerged macrophytes through diminished light penetration (Reid et al., 2007). This is implicated in ecological state shifts (Gell \& Reid, 2016; Figure 3) whereby turbid water, accompanied by elevated nutrient loads, has advantaged phytoplankton thereby altering food webs and habitat for invertebrates (Kattel et al., 2017). All the studied sites reveal change attributable to increased loads of nutrients, sediments and/or salts (Gell \& Reid, 2014). Today, these conditions are exacerbated in many wetlands by perennial connection to the River, which acts as a source of pollutants to floodplain wetlands and which appears to seed billabongs 
with river phytoplankton ensuring its dominance in primary production (Reid and Ogden 2009).

The increased sediment flux has a more fundamental risk by accelerating the rate at which off-channel billabongs in-fill and become terrestrialised, thus reducing the abundance of extant billabongs in these floodplain landscapes. Similarly, the more hydrologically variable and unpredictable rivers of the northern MDB, including its major river the Barwon-Darling, frequently cease to flow and may even dry to a series of isolated pools (Sheldon et al. 2010) that act as important aquatic refugia in these systems (Sheldon et al. 2010). A critical measure of their effectiveness as refugia is the period over which the waterhole retains water - which is determined largely by depth (Hamilton et al. 2005). Accelerated sedimentation in waterholes on several northern MDB rivers may persistence times and hence their value as refugia (Lobegeiger 2010, Reid et al. 2017).

The long-term record of change thus suggests that the main drivers operate at a large scale, are diffuse, persistent, entrenched (internal cycling) and so are likely ongoing. The drying climate has seen the lowering of saline water tables alleviating the risk of salinization, however, high nutrient and sediment loads, are legacies of past management that will not be easily remedied.

\section{Long term climate variability}

Inland Australia has a naturally, high amplitude, variable climate with irregular events superimposed on cycles of change with a range of frequencies (Mills et al., 2013). Contemporary climates reflect the extreme effects of the El Niño Southern Oscillation (ENSO) overlain on multidecadal cycles attributed to the Interdecadal Pacific Oscillation (IPO; Power et al., 1999). Similarly, the Indian Ocean Dipole (IOD) is an important influence on incursions of rainfall from the north-west of the continent (Webster et al., 1999). Likewise, the Southern Annular Mode (SAM) is associated with drier than average conditions over SE Australia and Tasmania when in positive phase (Gillett et al., 2006).

The drivers of prolonged droughts in Australia vary with different causes identified behind the Federation ( 1895-1902), World War II (1937-1945) and Millennium (2001-2009) events (van Dijk et al. 2013; Verdon-Kidd and Kiem, 2009). These extreme events had different 
patterns of rainfall deficits, severity and seasonality. The Federation Drought (most severe in the north and east) coincided with sustained El Niño conditions. The World War II drought covered most of the country when Sea Surface Temperatures were cooler than average near the northwest coast, implying a connection with the IOD. The Millennium drought was most intense in the southeast and was associated with a strongly positive phase of the SAM. Since multiple modes of climate variability have influenced past events, drivers of drought could combine in ways that generate even longer dry phases (Verdon-Kidd and Kiem, 2009). Hence, the aquatic systems of the MDB have evolved through high amplitude climate variability with both geomorphic and ethnohistoric evidence pointing to high amplitude floods, and multiple episodes of persistent drought. So, these ecosystems, renowned for their 'boom-and-bust' ecology, have shown considerable resilience to extended periods of drier conditions.

The present climate is likely drier than that of early European times, and is arguably now, or soon to be, outside the historical range for rainfall. Changes to regional circulation include the anomalous state of the SAM (Abrams et al., 2014) and the tendency for drier conditions over recent decades driven by the IOD and ENSO (Freund et al., 2019). This drying climate has driven reductions in runoff ( 25-50\%) compared with the past average (Mills et al., 2013).

The winter wet season could be truncated with the break in season arriving later and spring rainfall less likely to persist. Further, a diminished snowpack could reduce spring runoff in the southeast uplands, the principal source of irrigation water (CSIRO 2008). While summer rainfall events may increase this could be less effective than winter rain, and so the drying climate may amplify the contest for water between industry and the environment. Meanwhile, rising sea-levels will increase the tidal prism and reduce stream gradients with the terminal coastal wetlands the most sensitive to sea level and more frequent tidal inundation of freshwater systems is expected (Helfensdorfer et al., 2019).

\section{Restoration requires a multifaceted approach}

Climate variability and sea level change have influenced the wetlands of the MDB over a range of scales. The changes evident in wetland condition since European settlement have been widespread or even universal, and multi-faceted. Importantly, European settlers 
impacted upon the waterways of the southern MDB from soon after their arrival. The legacy of over 170 years of catchment development includes enhanced sedimentation in channels and floodplain lakes (Gell et al 2009), elevated sediment nutrient loads which may become bioavailable (Gell \& Reid, 2014), higher water tables leaking salts under wet conditions, and the replacement of clear water, macrophyte-dominated systems of the $19^{\text {th }}$ century with the turbid, phytoplankton-dominated states (Ogden 2000; Gell and Reid 2014; 2016). So, the antiquity and prolonged history of disturbance and degradation constitutes a challenge for programs seeking evidence for recovery from restoration measures (Gell 2016). Further, while the pre-disturbance nature of some perennial wetlands appears to have been relatively constant, others exhibited considerable 'natural' variation in state (Gell et al., 2005) complicating efforts to determine natural baseline state.

The present MDB Plan has focussed on allocating a greater proportion of the annual water yield for environmental purposes. The main means of recovering water for this allocation was through a cap-and-trade system whereby a limit on further abstraction was set in 1998, and the water rights of landholders separated from the title so that volumes could be traded without the sale of property. The market price then influenced whether a user would take up their allocation and seek to generate a marketable product, or whether that volume was traded, presumably to a user whose cost-benefit margins favoured purchase at market price. This process has seen water leave some communities eroding their socio-economic underpinnings, while directing water to high return crops such as almonds (Davies, 2019) and cotton, at the expense of dairy. In this way, the mechanism used to re-allocate water is not so much planned, but driven by market forces, which influence decisions immediately. Through this market the government is required to plan to buy water for environmental purposes.

\section{Adaptive management pathways as a long-term recovery framework}

The adaptive management pathways approach executes pre-defined programmes of measures to counter evolving pressures (here, within a river basin) (Wilby and Dessai, 2010; Poff et al., 2016; Wilby and Murphy, 2018). Importantly, it prioritises measures and levels the cost of urgent actions on the present generation, while spreading the total cost across generations by staging interventions over time. Adaptive management approaches have 
been widely applied, including for sequencing public water supply augmentation options in Adelaide (Beh et al., 2015), water resource allocation in the MDB (Abel et al., 2016), and for long-term water management in the Rhine Delta, Netherlands (Haasnoot et al., 2013).

The Thames Estuary 2100 (TE2100) Plan is among the earliest examples of adaptive management (Figure 4). The plan was designed to protect London from storm surge, sea level rise, and river water flooding over the 21st century and beyond. The plan has three key phases covering: 2010-2034 (maintain or upgrade existing flood defences and preserve areas for future flood storage); 2035-2070 (renew or replace existing tidal defences); and 2070 onwards (maintain the existing system and build a new barrier) (Wilby and Dessai, 2010). The height of storm surges is not expected to increase significantly, so the primary driver of flood risk is local sea level rise. However, the pace of future sea level change in the Thames is highly uncertain, so the Plan allows for measures to be brought forward in time or delayed.

Several generic aspects of TE2100 are transferrable to other long-term management plans, including future water allocation in the MDB. The common elements of an adaptive pathways approach are:

(1) Portfolios of adaptation options identified through inclusive and participatory stakeholder consultations. Preferred options are "low regret" (i.e. helpful regardless of the pace and direction of climate change) and non-constraining of future options. The intergenerational equity of options and implications for social cohesion is critical. Low regret options for the MDB might include improved on farm water efficiency, sediment and nutrient management.

(2) Trigger points or decision criteria that indicate the circumstances under which a given adaptation option might be invoked. Example triggers for the MDB could include farm income, wetland salinity, or an ecologically relevant river flow.

(3) Monitoring systems to track evolving socio-economic and environmental conditions leading to the triggers (2) above. Alternatively, adaptation options may be periodically reviewed at predefined decision stages. 
(4) Performance indicators to evaluate the outcomes of adaptation options using metrics relevant to the MDB such as water supply security (in terms of resilience and reliability), risk of water outages, meeting environmental flows, cost, or greenhouse gas emissions.

(5) Governance and institutional structures provide the informal and legal jurisdictions within which (1) to (4) operate. However, water governance regimes are themselves dynamic, as they adapt to changing social and cultural priorities, new knowledge, politicised processes for conflict resolution, and water policy reform.

The above elements are intended to deliver a flexible, iterative and open-ended approach to climate risk management - deemed 'dynamic robustness' (Maier et al., 2016). The following sections evaluate the extent to which such an idealized adaptive management framework could deliver long-term scheduling of options to restore degraded ecosystems in the MDB despite deep uncertainty about future climate change and water availability.

\section{A Plan to rehabilitate the wetlands of the MDB}

The Water Act (2007) established a legislative framework for restoring the aquatic ecosystems of the MDB by paving the way for the MDB Plan to recover water through buybacks and delivery infrastructure. The MDB Plan attracted resistance from communities and this exerted political pressure which drove amendments through the implementation of adjustments to the Sustainable Diversion Limits. However, as the Royal Commission into the MDB plan (Walker 2019) reinforced, the Water Act requires that government focus on environmental outcomes, independent of social and economic considerations; thereby, seemingly, authorizing government to take water for all the environmental flows needed to restore the environment

The MDB system was recognised as degraded and the primary cause of this poor condition was identified as the lack of river flows on account of the over-allocation of water for irrigation agriculture. So, the principal focus of the MDB Plan was on the recovery of water as the main driver of wetland restoration. While water quality decline is recognised as a contributing factor, water volume was the foremost target (Colloff et al., 2015) leaving most 
drivers of degradation, as identified from the long-term record (Gell \& Reid, 2016), to remain largely unaddressed.

Amongst the possible measures that may be implemented to restore wetlands, water recovery is the treatment that represents the greatest challenge to regional industry and so social resilience. The establishment of a 'Cap' and the separation of land and water rights provided for a cap-and-trade system that saw demand greatly influence the price of water. Water scarcity, variable water allocations and escalating prices have created considerable hardship for communities. While water trading has been voluntary, pressures have seen regions sell large volumes of allocated water impacting on the production and economies of some regions (RMCG 2016). Meanwhile, the 2018/19 season saw low to zero allocations to mid-catchment irrigators while rivers carried large volumes downstream to those with allocations. So, the focus on water recovery as the principal means to affect environmental restoration has levelled the greatest hardship on regional communities and eroded trust in the process that allocates water across the MDB.

Competition for water under the MDB Plan is acute, particularly under extreme drought conditions. Low flows during $2018 / 19$ were found to be a major contributor to unprecedented fish kills on the lower Darling River (Australian Academy of Science 2019; Vertessy et al 2019). As a result, the future of the MDB's waterways and socio-ecological systems has featured prominently as an issue in State and Federal elections. Social, economic and political pressures are likely to continue to increase, under a drying climate, if the focus on ecological restoration continues to be on water volume recovery. Hence, a concerted search for supplementary measures to mitigate the impacts of long-term degradation and arrest biodiversity decline (e.g. Baumgartner et al., 2019) could ease, at least in the short term, the social cost of the MDB Plan. Furthermore, this could avoid levelling most cost on the present generation whilst buying time to implement a MDB Plan with a mix of measures that is more equitable. In the MDB wetlands, paleo records reveal that sediment, nutrient and salt flux has greatly increased; that these are major drivers of wetland degradation and that the allocation of river water maintains the supply of these pollutants to wetlands. So, if the intention of the 
Act is ecological recovery, government should follow the Calow and Petts (1994) edict of repairing water quality before, or at least as, water is recovered. Yet, the legacy of change suggests mitigating sediment flux alone would require large scale management actions, and reduction in flux would take much time. Recovery of water is an effective measure to implement politically, but it levels greatest socio-economic cost on the present generation.

\section{A strategic adaptive management approach for the MDB}

There is already a wealth of studies on the evolving governance structures and strategic adaptive management of water resources in the MDB (e.g. Abel et al., 2016; Marshall and Alexandra, 2016; Conallin et al., 2018; Alexandra, 2019). These reveal the extent to which the approach can implement environmental flows within complex and highly contested socio-ecological contexts. Several important lessons have been learnt so far.

First, inclusiveness, commitment and transparency are essential for building trust and ownership of the process amongst stakeholders (Conallin et al., 2018). This involves structured co-design of initial options, triggers and performance indicators with participatory decision-making throughout. Stakeholders and experts should also be involved in the specification of measurable triggers or so called 'thresholds of potential concern' (e.g. fish survival or flow delivery frequencies).

Second, recognition that past institutional arrangements, policy paradigms and development patterns constrain present and future options, as well as the adaptability of institutions (Marshall and Alexandra, 2016). Infrastructure 'lock-in' and institutional pathway dependency both tend to limit innovation and reinforce the status quo. This has led to slow progress and high costs to taxpayers from implementation of the preferred measures such as water buy-backs from irrigators and capital subsidies for new supplydriven infrastructure projects. Hence, option sets are not always as unrestricted as they might be.

Third, assumptions about uncontested knowledge and shared goals may be too simplistic. In practice, it may be far from straightforward to agree thresholds for individual species - even amongst experts - let alone at the ecosystem or landscape scale. Unlike TE2100, where 
there is a single, dominant driver (i.e. sea level change), wetland systems in the MDB must be adaptively managed in the context of multiple pressures. Diagnostic problem-structuring methods can help to explore different framings of the issues around competing goals, values and scientific uncertainties (e.g. Bosomworth et al., 2017).

Fourth, outcomes of measures may be more uncertain than anticipated - the expected ecosystem response to water (re)allocation in the MDB are fuzzy rather than deterministic. Attention tends to focus more on the uncertainty in regional climate change, socioeconomic futures and the planning environment. However, careful project management and strong communications between stakeholders can help to manage changing expectations and indicators of 'success' (Sellberg et al., 2018). Further, an a priori planning approach, that clearly states the pace of change to be implemented, the compensation and the expected level of benefit accruing from the measures, is likely to begin the process of rebuilding trust in management by government and so ease the level of conflict.

\section{What prescriptions for restoration emerge and how should these be rolled out?}

The present approach focussing on the recovery of water from primary producers under a cap-and-trade system, and the allocation of that water to environmental flows, is an attractive solution to the now volatile issue of the state of MDB waterways. While there is considerable resistance, the market allows government to purchase water at the trading table, rather than compulsorily acquire it, and so have an ongoing capacity to control its allocation. Also, the actions and the response are relatively easy to report and credit for action is readily accrued by those responsible. Also, it is a simple, and easily digestible approach and attracts support from interests that are not fully versed in the complexities of ecosystem restoration. So, while it is clear that many wetlands are in need of water and rivers of flows, the focus on recovering consumptive water for environmental purposes is attractive politically and it can be demonstrated to be beneficial, provided that society's expectations of the recovery process are limited to their recollection of recent conditions.

Finlayson et al. (2016) observed that if the target for restoration is that recognised in recent times, then a risk exists that all past drivers of degradation are excused. The long term palaeoecological record identifies a prior condition that was much more productive and 
diverse, and likely more resilient to a variable climate, but a short term view would preclude this as a justifiable target for MDB restoration. Also, a better understanding of the path to degradation is likely to reveal the full suite of the drivers of change and enable management to better prioritise investment in restoration. Clearly, there has been a long history of impacts other than regulation, diversion and abstraction, so water recovery remains only one of the restorative measures required to recover the ecological assets and function of the past. As Ogden (2000: 497) observed "attempts to rehabilitate rivers through environmental flows will fail unless steps are taken to remedy farm impacts". A similar emphasis on managing headwater pressures has been recognized elsewhere (Riley et al., 2018).

The adoption of multiple measures would both allow restoration to target a broad range of stressors, and not just those affected by water flow or availability, but also, by spreading the focus, it may alleviate the acute short-term pressures on the regional communities. While the investment in land and riparian management will still constitute a considerable cost to the broader community and economy, it will ensure a far greater and more robust ecological outcome from the investment in the water, that is denied primary production, and so it will be a more defensible investment than under a focus on water alone without supplementary measures. A challenge also exists in the time required to see benefits arise from land management compared with water recovery. This will demand effective communication of a plan that aims to implement measures in a structured manner with the costs spread and the challenges met as they approach.

While the Water Act provides a justification for recovering ecosystem function independent of the social and economic cost, the mere provision of water volume for environmental flows and wetland inundation is likely to fall short of achieving baseline ecological function and biological diversity. Thus, we argue that the management of the flux of sediments, nutrients and salts, in parallel with the recovery of water for environmental purposes, satisfies the demands of the Water Act by providing the best means of achieving ecological recovery. This would spread the cost from a user-pays principal, to the community more generally which can be justified owing to the encouragement by government historically for farmers to develop land and make use of the readily available water resource. It may allow for targets for environmental water to be better directed and justified reducing the short- 
term demand for water recovery and, more convincingly demonstrating the benefits of the volumes recovered. Importantly, it may provide a release of the pressure valve that has arisen through the resources contest that is a consequence of the focus on the recovery of water volume alone.

This approach may allow for the implementation of an adaptation pathways which both enacts actions to arrest ecosystem degradation and begin the long pathway to restoration, while developing a timeline of restorative measures that are more diverse than at present. While one of these measures is likely to be water recovery, this is just one option within a more holistic approach to ecosystem recovery, that addresses a wide range of ecological stressors, and manages the cost to socio-ecological systems. In concert with the supplementary measures, it is possible that water recovery may be implemented in a stepwise fashion, easing the immediate impact and spreading the cost across future generations. This pathway may allow time for the phased development and implementation of water use efficiency measures or shifts in the regional agricultural economy (Figure 5) allowing for sustainable adaptation over time of the socio-ecological systems. This will be required on account of the historic over-allocation, but also as an adaptation to expected diminished runoff under a drying regional climate which is likely to intensify competition for water.

\section{Conclusions}

The MDB has had a long history of human impact, particularly since the rapid expansion of water regulation in the early $20^{\text {th }}$ century. This government sponsored water resource development drove high levels of production within the MDB which underpins the socioecological system. Subsequent recognition of the attendant degradation of natural ecosystems focused attention on the recovery of consumptive water under a cap-and-trade approach to create an environmental flows pool, as the key means of restoring waterway function. However, the multi-faceted, deep-in-time drivers of ecosystem decline must be addressed by a more nuanced and planned approach to restoration. 
A structured, adaptation pathways approach represents a solution to the high level of conflict over the management in the MDB in that it would act to rehabilitate the system over time, without undermining critical regional industries and dependent communities. This approach would phase in water recovery and direct these resources to sites identified as in critical need. It would re-direct a proportion of that investment in water recovery towards measures that improve biodiversity outcomes (e.g. Baumgartner et al., 2019) but that minimize economic hardship on communities. It would invest in means of removing water from once intermittent, permanent wetlands and reinstate wetting and drying cycles to reset their ecological state.

While the risks of a drying climate on the function of the socio-ecological systems of the MDB remains contested in some quarters, the long lead time for planning such an eventuality requires that adaptive planning be implemented at an early stage. To date, the impact of reduced rainfall and runoff in the southern MDB has been underplayed and this is likely to lead to more precipitous adaptation when the risk is recognised. Given some major infrastructure projects can take decades to move from plan to operation, the adaptation pathways approach provides a means of planning a sequence of investment so that infrastructure is in place when water stressful conditions arise. Further, should scenarios of $15 \%$ less rainfall and up to $40 \%$ less runoff materialize, then the mix of regional industry required may need to be focussed more on dryland, than irrigated agriculture. The establishment of a managed pathway to this future, rather than a laissez-faire, free market approach, is a more just solution to deal with foreseeable stresses. Rather than leaving industries and communities to collapse through economic forces it provides a means by which government can support regional communities to develop the resilience necessary to adapt, innovate and transition ahead of changes in water availability.

Finally, we close by acknowledging that an adaptive management approach to river restoration with an emphasis on rehabilitating floodplain refugia first, were ideas expounded by Geoff Petts 25-years ago in the Rivers Handbook. Since then, the pace of global change and attendant pressures on natural systems have made his views even more prescient than before. 


\section{Data Availability Statement}

The data that support the findings of this study are available from the corresponding author upon reasonable request

\section{References}

Abram, N. J., Mulvaney, R., Vimeux, F., Phipps, S.J., Turner, J. and England, M.H. (2014). Evolution of the Southern Annular Mode during the past millennium. Nature Climate Change, 4, 564-569.

Abel, N., Wise, R., Colloff, M., Walker, B., Butler, J., Ryan, P., Norman, C., Langston, A., Anderies, J.M., Gorddard, R., Dunlop, M. and O'Connell, D. (2016). Building resilient pathways to transformation when "no one is in charge": insights from Australia's Murray-Darling Basin. Ecology and Society, 21(2), art 23.

Alexandra, J. (2019) Losing the authority-what institutional architecture for cooperative governance in the Murray Darling Basin? Australasian Journal of Water Resources, doi.org/10.1080/13241583.2019.1586066.

Australian Academy of Science (2019). Investigation of the causes of mass fish kills in the Menindee Region NSW over the summer of 2018-2019. Australian Academy of Science, Canberra.

Baumgartner, L.J., Gell, P., Thiem, J.D., Finlayson, C.M. and Ning, N. (2019). Ten complementary measures to assist with environmental watering programs in the Murray-Darling river system, Australia. River Research \& Applications.

Beh, E. H., Maier, H. R. and Dandy, G. C. (2015). Adaptive, multiobjective optimal sequencing approach for urban water supply augmentation under deep uncertainty. Water Resources Research, 51(3), 1529-1551.

Bosomworth, K., Leith, P., Harwood, A. and Wallis, P.J. (2017). What's the problem in adaptation pathways planning? The potential of a diagnostic problem-structuring approach. Environmental Science \& Policy, 76, 23-28. 
Calow, P. and Petts, G.E. (1994). The Rivers Handbook: Science and Management of River Environments. Wiley-Blackwell, Oxford.

Clarkson, C., Jacobs, Z., Marwick, B., Fullagar, R., Wallis, L., Smith, M., Roberts, R.G., Hayes, E., Lowe, K., Carah, X., Florin, A., McNeil, J., Cox, D., Arnold, L.J., Hua, Q., Huntley, J., Brand, H.E.A., Manne, T., Fairbairn, A., Shulmeister, J., Lyle, L., salinas, M., Page, M., Connell, K., Park, G., Norman, K., Murphy, T. and Pardoe, C. Human occupation of northern Australia by 65,000 years ago. Nature, 547, 306-310. doi: 10.1038/nature22968.

Colloff, M.J., Caley, P., Saintilan, N., Pollino, C.A. and Crossman, N.D. (2015). Long-term ecological trends of flow-dependent ecosystems in a major regulated river basin. Marine and Freshwater Research, 66(11), 957-969.

Commonwealth of Australia, 1996. Australia: State of the Environment 1996. CSIRO, Collingwood.

Conallin, J., Campbell, J. and Baumgartner, L. (2018). Using strategic adaptive management to facilitate implementation of environmental flow programs in complex socialecological systems. Environmental Management, 62(5), 955-967.

CSIRO. (2008). Water Availability in the Murray-Darling Basin. A report to the Australian Government from the CSIRO: CSIRO, Australia.

Davidson, T. A., Reid, M. A., Sayer, C. D. and Chilcott, S. (2013). Palaeolimnological records of shallow-lake biodiversity change: exploring the merits of single versus multi-proxy approaches. Journal of Paleolimnology, 49, 431-446. doi:10.1007/s10933-013-9696-8

Davies, A. (2019). Tough nut to crack: the almond boom and its drain on the Murray-Darling. The Guardian Australia. Accessed May 30 2019.

Davies, P., Lawrence, S., Turnbull, J., Rutherfurd, I., Grove, J., Silvester, E. ... Macklin, M. (2018). Reconstruction of historical riverine sediment production of the goldfields of Victoria, Australia. Anthropocene, 21, doi.org/10.1016/j.ancene.2017.11.005. 
Davies, P. E., Harris, J. H., Hillman, T. and Walker, K. F. (2010). The Sustainable Rivers Audit: Assessing river ecosystem health in the Murray-Darling Basin, Australia. Marine \& Freshwater Research, 61, 764-777.

Davis, J., Murray, S. and Burchell, F.N. (1902). Interstate Royal Commission on the River Murray, representing the states of New South Wales, Victoria, and South Australia: report of the Commissioners with Minutes of evidence, appendices, and plans. Parliament of Victoria, Melbourne.

Dubois, N., Saulnier-Talbot, E., Mills, K., Gell, P., Battarbee, R., Bennion, H. ... Valero-Garcés, B. (2018). First human impacts and responses of aquatic systems: A review of palaeolimnological records from around the world. The Anthropocene Review, 5, 2868.

Finlayson, C.M., Clarke, S.J., Davidson, N.C. and Gell, P. (2016). Role of palaeoecology in describing the ecological character of wetlands. Marine \& Freshwater Research, 67, 687-694.

Freund, M.B., Henley, B., Karoly, D.J., McGregor, H.V, Abram, N.J. and Dommenget, D. (2019). Higher frequency on Central Pacific El Niño events in recent decades. Nature Geoscience

Gell, P.A. (2016). Prospects for Ecological Recovery in Wetlands Limited by Muddy Murray Flows. Proceedings of the International Ecohydraulics Conference, Melbourne, 7-12 February, 2016.

Gell, P.A. (2019). Restoring Murray River floodplain wetlands: Does the sediment record inform on watering regime? River Research \& Applications.

Gell, P., Fluin, J., Tibby, J., Hancock, G., Harrison, J., Zawadzki, A. ... Walsh, B. (2009). Anthropogenic Acceleration of Sediment Accretion in Lowland Floodplain Wetlands, Murray-Darling Basin, Australia. Geomorphology, 108, 122-126.

Gell, P. and Reid, M. (2014). Assessing change in floodplain wetland condition in the Murray Darling Basin. The Anthropocene, 8, 39-45. 
Gell, P. and Reid, M. (2016). Muddied Waters: the case for mitigating sediment and nutrient flux to optimize restoration response in the Murray-Darling Basin, Australia. Frontiers in Ecology and Evolution, 4: art \# 16.

Gell, P., Bulpin, S., Wallbrink, P., Bickford, S. and Hancock, G. (2005). Tareena Billabong - A palaeolimnological history of an everchanging wetland, Chowilla Floodplain, lower Murray-Darling Basin. Marine and Freshwater Research, 56, 441-456.

Gillett, N.P., Kell, T.D. and Jones, P.D. (2006). Regional climate impacts of the Southern Annular Mode. Geophysical Research Letters, 33(23), L23703.

Haasnoot, M., Kwakkel, J. H., Walker, W. E. and ter Maat, J. (2013). Dynamic adaptive policy pathways: A method for crafting robust decisions for a deeply uncertain world. Global Environmental Change, 23(2), 485-498.

Hamilton, S. K., Bunn, S. E., Thoms, M. C. and Marshall, J. C. (2005). Persistence of aquatic refugia between flow pulses in a dryland river system (Cooper Creek, Australia). Limnology and Oceanography, 50(3), 743-754.

Helfensdorfer, A.M., Power, H.E. and Hubble, T.C.T. (2019). Modelling Holocene analogues of coastal plain estuaries reveals the magnitude of sea-level threat. Nature Scientific Reports, doi.org/10.1038/s41598-019-39516-4.

Jones, V. (2019). Murray Darling Basin Plan protesters descend in Albury in hopes of 'pausing the plan'. Canberra Times, April 10.

Kattel, G., Gell, P., Zawadzki, A. and Barry, L. (2017). Palaeoecological evidence for sustained change in a shallow Murray River (Australia) floodplain lake: regime shift or press response? Hydrobiologia, 787(1), 269-290.

Lobegeiger, J. S. (2010). Refugial waterholes project. Research highlights. Queensland Department of Environment and Resource Management, Brisbane.

Macumber P. (1991). Interaction between groundwater and surface systems in northern Victoria. Department of Conservation and Environment, Victoria, Melbourne. 
Maier, H. R., Guillaume, J. H., van Delden, H., Riddell, G. A., Haasnoot, M. and Kwakkel, J. H. (2016). An uncertain future, deep uncertainty, scenarios, robustness and adaptation: How do they fit together? Environmental Modelling \& Software, 81, 154-164.

Marshall, G.R. and Alexandra, J., (2016). Institutional path dependence and environmental water recovery in Australia's Murray-Darling Basin. Water Alternatives, 9(3), 679-703.

MDBA, 2013. MDBA Basin Plan. Murray Darling Basin Authority, Canberra.

Millennium Ecosystem Assessment (2005). Ecosystems and human well-being: Wetlands and water synthesis. World Resources Institute, Washington, DC.

Mills, K., Gell, P., Gergis, J., Baker, P.J., Finlayson, C. M., Hesse, P.P. ... Tibby, J. (2013) Paleoclimate studies and natural-resource management in the Murray-Darling Basin II. Unravelling human impacts and climate variability. Australian Journal of Earth Sciences, 60, 561-571.

Morton, S. R., Smith, D. M. S., Friedel, M. H., Griffin, G. F., \& Pickup, G. (1995). The Stewardship of Arid Australia - Ecology and Landscape Management. Journal of Environmental Management, 43(3), 195-217.

Ogden, R.W. (2000). Modern and historical variation in aquatic macrophyte cover of billabongs associated with catchment development. Regulated Rivers: Research \& Management, 16, 497-512.

Ogden, R. W., Reid, M. A., \& Thoms, M. C. (2007). Soil fertility in a large dryland floodplain: patterns, processes and the implications of water resource development. Catena, 70(2), 114-126.

Poff, N.L., Brown, C.M., Grantham, T.E., Matthews, J.H., Palmer, M.A., Spence, C.M., Wilby, R.L., Haasnoot, M., Mendoza, G.F., Dominique, K.C. and Baeza, A. (2016). Sustainable water management under future uncertainty with eco-engineering decision scaling. Nature Climate Change, 6, 25-34.

Power, S., Casey, T., Foland, C., Colman, A. and Mehta, V. (1999). Inter-decadal modulation of the impact of ENSO on Australia. Climate Dynamics, 15, 319-322. 
600

601

602

603

604

605

606

607

608

609

610

611

612

613

614

615

616

617

618

619

620

621

622

623

624

625

626

Ranger, N., Reeder, T. and Lowe, J. (2013). Addressing 'deep' uncertainty over long-term climate in major infrastructure projects: four innovations of the Thames Estuary 2100 Project. EURO Journal on Decision Processes, 1, 233-262.

Reid, M. A., Sayer, C. D., Kershaw, A. P. and Heijnis, H. (2007). Palaeolimnological evidence for submerged plant loss in a floodplain lake associated with accelerated catchment soil erosion (Murray River, Australia). Journal of Paleolimnology, 38, 191-208.

Reid, M. A. and Ogden, R. W. (2009). Factors affecting diatom distribution in floodplain lakes of the southeast Murray Basin, Australia and implications for palaeolimnological studies. Journal of Paleolimnology, 41(3), 453-470.

Reid, M. A., Bickford, S., Gell, P. A., \& Kenyon, C. E. (2016). A history of Australia's riverine habitats and vegetation. In S. J. Capon, C. James, \& M. A. Reid (Eds.), Vegetation of Australian Riverine Landscapes (pp. 45-64). Clayton: CSIRO Publishing.

Reid, M. A., Thoms, M. C., Chilcott, S. and Fitzsimmons, K. (2017). Sedimentation in dryland river waterholes: a threat to aquatic refugia? Marine and Freshwater Research, 68, 668-685. doi:http://dx.doi.org/10.1071/MF15451

Riley, W.D., Potter, E.C.E., Biggs, J., Collins, A.L., Jarvie, H.P., Jones, J.I. ... Siriwardena, G.M. (2018). Small Water Bodies in Great Britain and Ireland: Ecosystem function, humangenerated degradation, options for restorative action. Science of the Total Environment, 645, 1598-1616.

RM Consulting Group (2016). Basin Plan - GMID socio-economic impact assessment - final report. RMCG, Bendigo.

Sellberg, M.M., Ryan, P., Borgström, S.T., Norström, A.V. and Peterson, G.D. (2018). From resilience thinking to Resilience Planning: Lessons from practice. Journal of Environmental Management, 217, 906-918.

Sheldon, F., Bunn, S. E., Hughes, J. M., Arthington, A. H., Balcombe, S. R. and Fellows, C. S. (2010). Ecological roles and threats to aquatic refugia in arid landscapes: dryland river waterholes. Marine and Freshwater Research, 61(8), 885-895. 
Van Dijk, A.I.J.M., Beck, H.E., Crosbie, R.S., de Jeu, R.A.M., Liu, Y.Y., Podger, G.M. ... Viney, N.R. (2013). The Millennium drought in southeast Australia (2001-2009): natural and human causes and implications for water resources, ecosystems, economy, and society. Water Resources Research, 49, 1040-1057.

Verdon-Kidd, D.C. and Kiem, A.S. (2009). Nature and causes of protracted droughts in southeast Australia: Comparison between the Federation, WWII, and Big Dry droughts. Geophysical Research Letters, 36, L22707.

Vertessy, R., Barma, D., Baumgartner, L., Mitrovic, S., Sheldon, F. and Bond, N. (2019). Independent assessment of the 2018-19 fish deaths in the Lower Darling. Interim Report to the Minister for Agriculture and Water Resources.

Walker, B. (2019). Murray-Darling Basin Royal Commission Report. South Australia, Government of South Australia,

Wilby, R.L. and Dessai, S. (2010). Robust adaptation to climate change. Weather, 65, 180185.

Wilby, R.L. and Murphy, C. (2018). Decision making by water managers despite climate uncertainty. In: Pfeffer, W.T., Smith, J.B. and Ebi, K.L. (eds.) Oxford Handbook of Planning for Climate Change Hazards. Oxford University Press, Oxford.

Webster, P.J., Moore, A.M., Loschnigg, J.P. and Leben, R.P. (1999). Coupled oceanatmosphere dynamics in the Indian Ocean during 1997-1998. Letters to Nature, 401 (6751), 356-360. 
Figure 1. The rainfall distribution across the MDB. The Murray (south) and Darling (north) sub-catchments are delineated by the dashed line.

Figure 2. The development of MDB water resources in a climatic context (FDR $=$ flood dominated regime; DDR = drought dominated regime). Source: Bureau of Meteorology website; CoA (1996)

Figure 3. Changes in wetland ecosystems recorded in sediments of wetlands on the central Murray River (a-c; e-g) and lower Murrumbidgee River ( $d$ \& h) floodplains. The upper panels show MDS ordination axis 1 scores from four wetlands (a. Hogan's 1, b. Hogan's 2, c. Iona $2, \mathrm{~d}$. Russell's). These scores reflect the relative abundance of phytoplankton in the sediment records, with high axis 1 scores indicating low phytoplankton and low axis 1 scores indicating high phytoplankton abundance (Gell and Reid 2016). The lower panel shows magnetic susceptibility values recorded in the corresponding sediment records. Higher values indicate higher inputs of eroded soil.

Figure 4. High-level options (HLOs) and adaptation pathways developed by the Thames Estuary 2100 strategy. The top axis shows thresholds for sea level change that trigger pre-defined measures. $\mathrm{H}++$ is a plausible, high-end climate change scenario that is used in the UK for sensitivity testing and appraisal of adaptation options. Source: Ranger et al. (2013). Reproduced with Permission from Springer Nature.

Figure 5. Possible adaptation pathways approach to future water allocation and supplementary management measures under a scenario of declining runoff. 
$670 \quad$ Figure 1

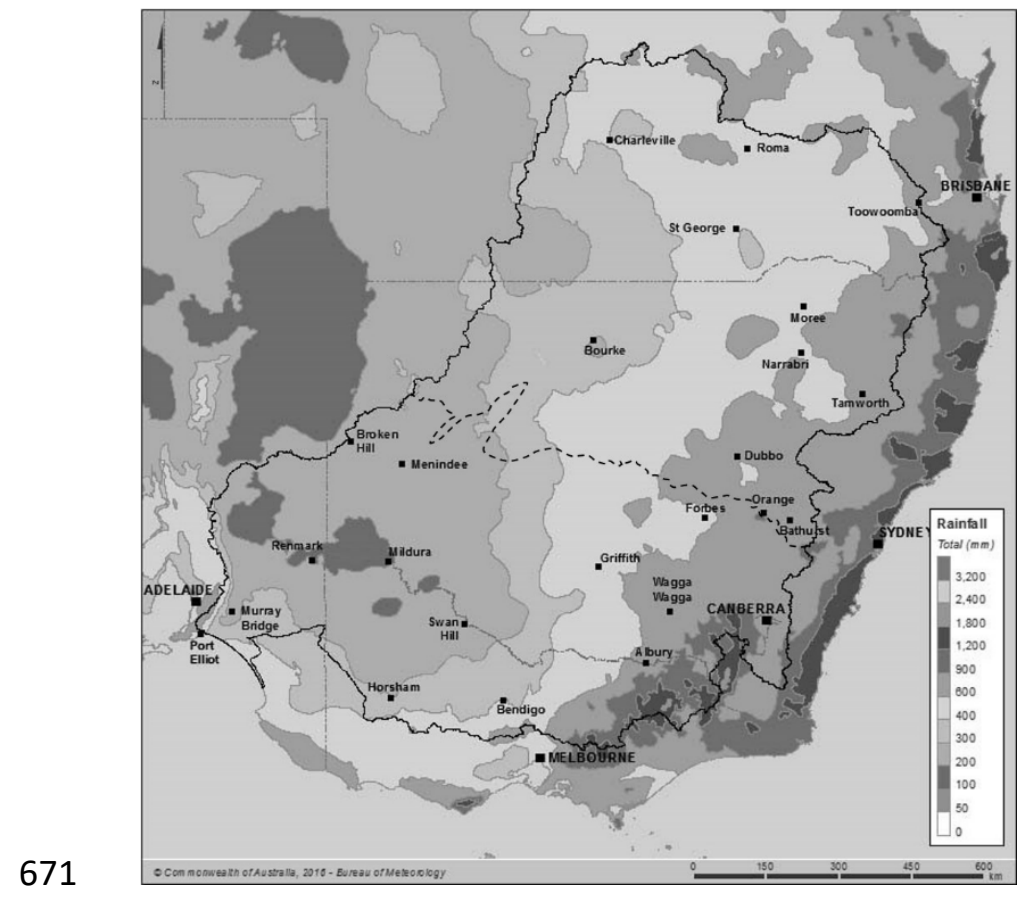

672

673 
Figure 2

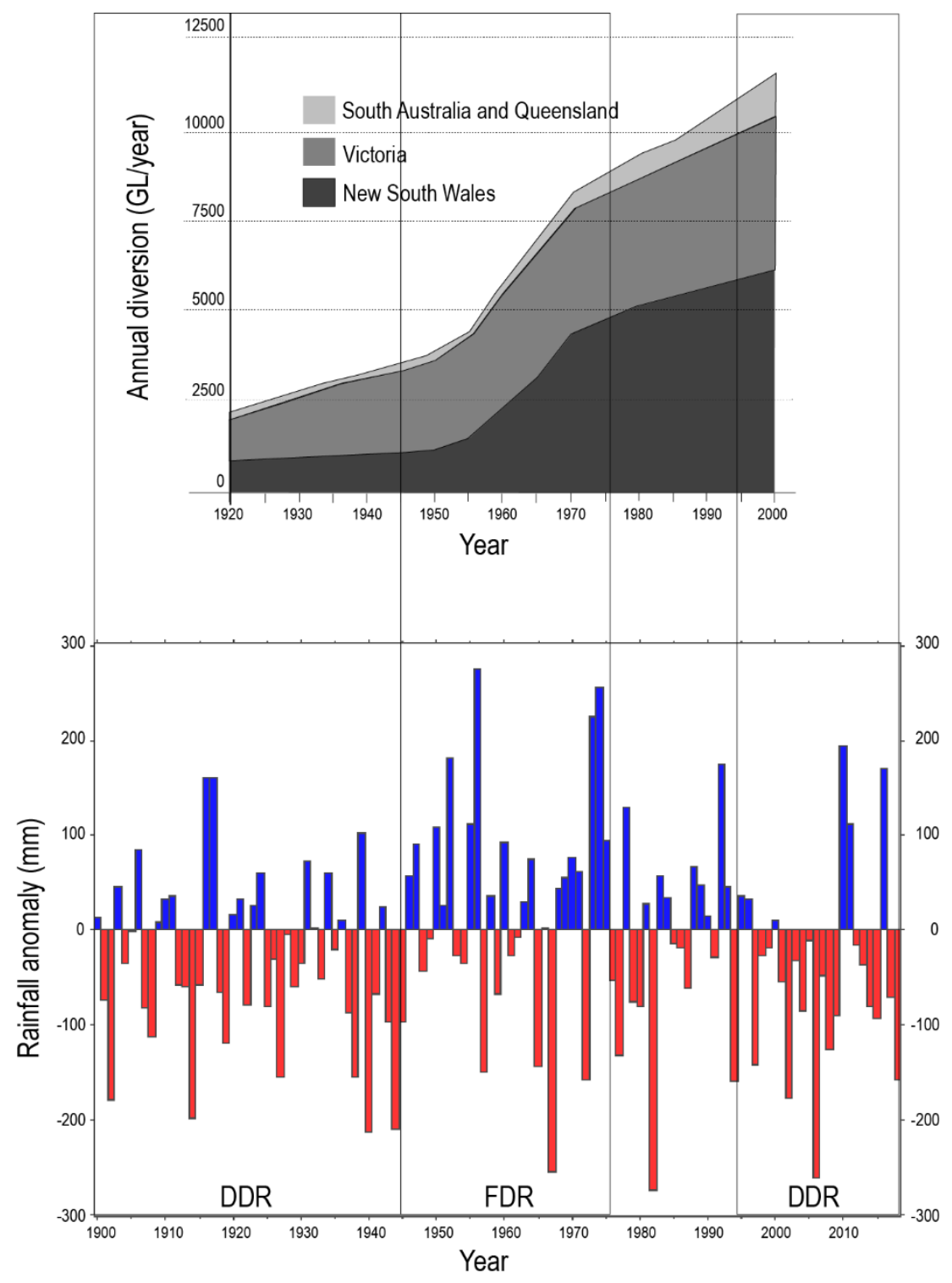

675

676 
$677 \quad$ Figure 3
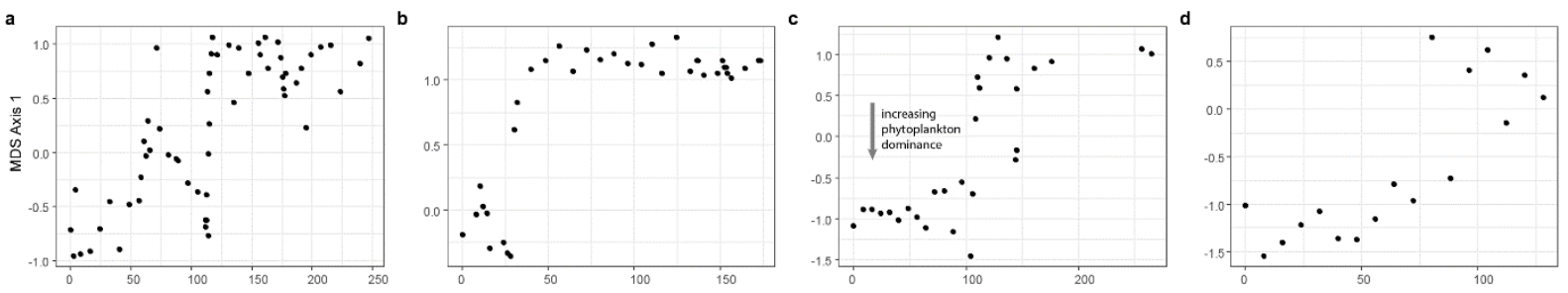

678


679

680 
$681 \quad$ Figure 4

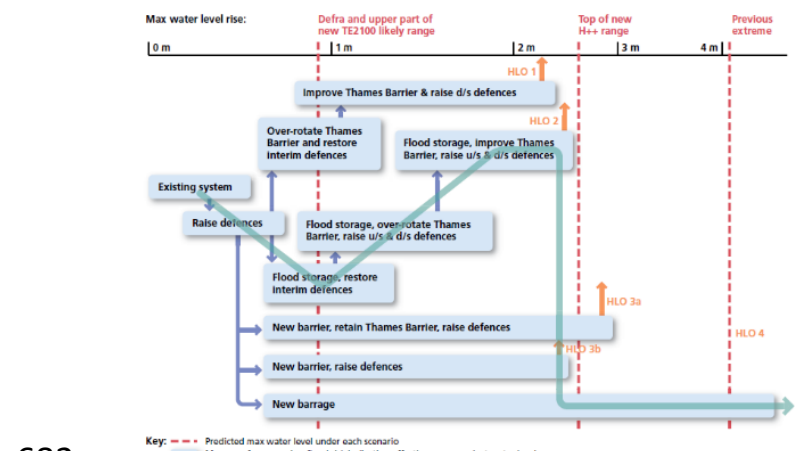

682

683

684 
$685 \quad$ Figure 5

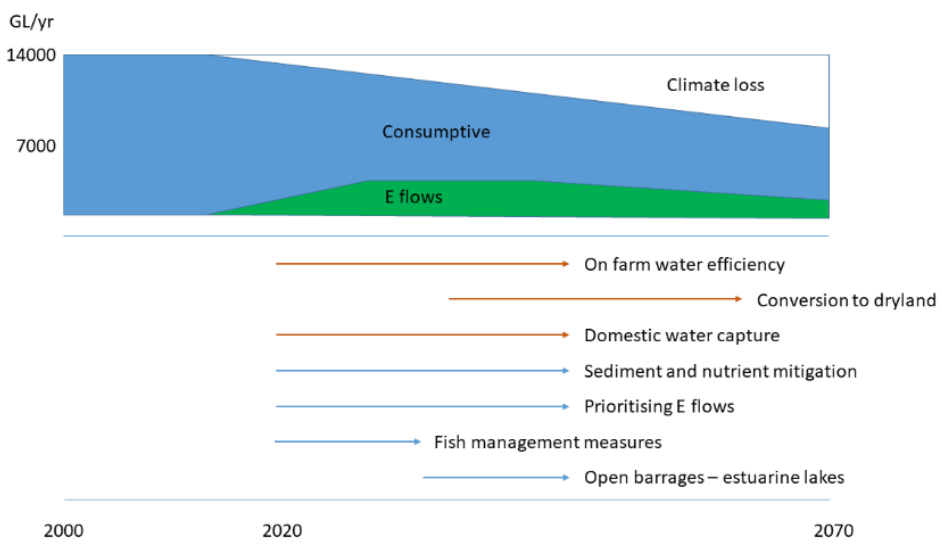

686 